\title{
PERKEMBANGAN HUKUM ADMINISTRASI NEGARA DI INDONESIA
}

\author{
FAUZAN ZAKIR \\ Sekolah Tinggi Ilmu Hukum Padang
}

\begin{abstract}
In general, its administration and formulation leads us to the administrative reality which is a milestone of the government to conduct and run its government. The law becomes the main basis in carrying out life to guarantee the principles of order and discipline so that there is order, ensuring a sense of independence, a sense of security, comfort, and order. The law is an umbrella between all types of human actions and behavior to achieve the principle of human protection. Sanctions are an important concluding part of law, also in administrative law. Generally there is no point in including obligations or prohibitions for citizens in state administrative legislation, when rules of conduct cannot be imposed by state administration (in the case where necessary). Furthermore, the implementation of a government sanction is valid as a decision (determination) which gives a burden to the parties. That brings with it the nature (nature) of sanctions.
\end{abstract}

Keywords: Branching. State Administrative Law, Indonesia.

\begin{abstract}
Abstrak: Secara umum mengenai administrasi dan perumusannya menghantarkan kita pada realitas administratif yang menjadi tonggak pemerintah untuk melakukan dan menjalankan pemerintahannya. Hukum menjadi dasar utama dalam melangsungkan kehidupan untuk menjamin asas tertib dan disiplin agar berlangsung keteraturan, terjaminnya rasa kemerdekaan, rasa aman-nyaman, dan tertib. Hukum menjadi payung diantara segala jenis tindak dan perilaku manusia untuk mencapai asas perlindungan manusia. Sanksi-sanksi merupakan bagian penutup yang penting di dalam hukum, juga dalam hukum administrasi. Pada umumnya tidak ada gunanya memasukkan kewajiban-kewajiban atau larangan- larangan bagi para warga didalam peraturan perundang-undangan tata usaha negara, manakala aturan-aturan tingkah laku tidak dapat dipaksakan oleh tata usaha negara (dalam hal dimaksud diperlukan). Selanjutnya pelaksanaan suatu sanksi pemerintahan berlaku sebagai suatu keputusan (ketetapan) yang memberikan beban belastende beschkking. Hal itu membawa serta hakikat (sifat) dari sanksi.
\end{abstract}

Kata Kunci: Perkemabangan. Hukum Adminisatrasi Negara, Indonesia.

\section{A. Pendahuluan}

Mengawali pembahasan pengertian dan pemahaman secara umum mengenai administrasi tentunya terlebih dahulu mengenal dan memahami apa itu administrasi dalam kajian ketatanegaraan, oleh karenanya konsep administrasi yang diterapkan dalam sistem ketatanegaraan saat ini mengalami banyak perkembangan dari sistem administrasi sebelumnya dikarenakan pola dan sistem baru yang kompleks menyesuaikan kebutuhan dan perkembangan globalisasi dan kebutuhan pelayanan yang modern.

Administrasi secara umum dapat diartikan sebagai suatu proses yang dilakukan secara kerjasama untuk mencapai tujuan bersama yang telah ditentukan sebelumnya. Apabila diterapkan secara formal dalam organisasi maka proses kerjasama tersebut adalah dalam upaya mewujudkan tujuan organisasi.

Adapun pendapat beberapa para ahli tentang pengertian administrasi, menurut William H. Newman dalam Handayaningrat (1996:2), bahwa "Administrasi adalah E-ISSN: 2657-0300 Lembaga Penelitian dan Penerbitan Hasil Penelitian Ensiklopedia $\quad 39$ 
sebagai bimbingan, kepemimpinan dan pengawasan dari pada usaha-usaha kelompok individu-individu terhadap tercapainya tujuan bersama".

S.P. Siagian (1971: 13-15) berpendapat tentang administrasi sebagai berikut: Dari terselenggaranya administrasi yang baik tentunya menjamin adanya kerjasama antar setiap individu, proses ini pada prinsipnya bukan ukuran adanya kepuasan ataupun tingkat keberhasilan diakhir kerjasamanya, esensinya administrasi hanya menjadi jembatan untuk menuju arah berproses sebuah nilai-nilai kebutuhan dan manfaat akan pekerjaan. Administrasi yang baik tentu adanya kesinambungan antara dua orang atau lebih dalam kelompok tertentu yang saling mempunyai tujuan baik terhadap apa yang dicita- citakannya itu.

Seorang manusia tidak dapat bekerja sama dengan dirinya sendiri, karena itu harus ada orang lain yang secara sukarela atau dengan cara lain diajak turut serta dalam proses kerjasama itu, dalam tujuan terlalu sering orang beranggapan bahwa tujuan dari pada proses administrasi harus selalu ditentukan oleh orang-orang yang bersangkutan berlangsung dengan proses itu, tujuan yang hendak dicapai dapat ditentukan oleh semua orang yang langsung terlibat dalam proses administrasi itu, tugas dan pelaksanaannya, berbicara mengenai tugas dan pelaksanaannya, sering pula beranggapan bahwa proses administrasi baru timbul apabila ada kerjasama, peralatan dan perlengkapan, peralatan dan perlengkapan yang diperlukan dalam proses administrasi tergantung berbagai faktor seperti: (1) jumlah orang yang terlibat dalam proses itu, (2) sifat tujuan yang hendak dicapai, (3) ruang lingkup serta aneka ragamnya tugas yang hendak dijalankan dan (4) sifat kerjasama dapat diciptakan dan dikembangkan.

Usaha hidup bersama merupakan itikad dan naluri manusia, oleh karena manusia tidak dapat melangsungkan kehidupannya dengan baik, kebersamaan itu memang diperlukan oleh manusia oleh karena manusia itu pada hakekatnya adalah mahluk sosial. Akan tetapi, usaha bersama itu diciptakan dan dikembangkan oleh manusia bukan saja oleh karena manusia itu adalah mahluk sosial, akan tetapi oleh karena kebutuhan (S.P. Siagian 1972: 34).

Philipus M. Hadjon, dkk (2002: 26) sebagaimana mengutip pendapat Prajudi Atmosudirjo menjelaskan pengertian administrasi negara sebagai berikut: Administrasi yang secara khas tercapainya tujuan yang bersifat kenegaraan (publik), artinya tujuantujuan yang ditetapkan Undang-undang secara "dwingend recht" (hukum yang memaksa). Selanjutnya dijelaskan oleh Prajudi Atmosudirjo secara umum "administration" dirumuskan sebagai "the overall management or control of organization".

Miftah Thoha (1991: 185) sebagaimana mengutip pendapat The Liang Gie menyatakan bahwa perumusan administrasi adalah segenap proses penyelenggaraan dalam setiap usaha kerjasama sekelompok manusia untuk mencapai tujuan tertentu. Sedangkan dari dalam pengertian lainnya administrasi adalah suatu sistem di dalam bekerjasama tersebut yang mempermudah usaha mencapai tujuan organisasi.

Selanjutnya dijelaskan A.W. Widjaja (1990: 7) ada 3 (tiga) konotasi administrasi: a) administrasi diartikan sebagai kegiatan ketatausahaan yang meliputi pengelolaan penciptaan informasi kedalam warkat-warkat tertentu, penggandaan, pengiriman dan penyimpanan informasi yang telah dijadikan warkat tersebut. b) administrasi diartikan sebagai proses kegiatan yang dilakukan oleh sekelompok orang yang bekerja sama 
untuk mencapai suatu tujuan tertentu. c) administrasi diartikan sebagai negara atau perusahaan.

Sejalan dengan kebutuhan dan perkembangan dunia pekerjaan dan pelayanan pemerintah terhadap masyarakat, seiring dengan pertumbuhan dan perkembangan tersebut secara langsung memenuhi berbagai aspek pelayanan masyarakat yang kini semakin beragam semakin memperkaya ranah dan perilaku administrasi dalam pengembangan ilmu dan perkembangannya di masyarakat. Pertumbuhan dan perkembangan tersebut tentunya memerlukan sarana dan prasarana yang cukup dan memadai untuk kebutuhan pelayanan masyarakat.

\section{B. Metodologi Penelitian}

Untuk melakukan penelitian ini dan untuk melengkapi bahan-bahan atau data yang konkrit, jawaban yang objektif dan ilmiah serta dapat dipertanggung jawabkan kebenarannya, maka penulis menggunakan metode penelitian pendekatan yuridis normatif terkait perkembangan hukum administrasi negara di Indonesia.

\section{Hasil dan Pembahasan}

Menurut H.A Simon dalam Handayaningrat(1992:2), bahwa "Administrasi yaitu sebagai kegiatan dari pada kelompok mengadakan kerjasama untuk menyelesaikan suatu pekerjaan berdasarkan yang telah ditetapkan". Pendapat di atas dapat disimpulkan bahwa administrasi merupakan sebuah kegiatan yang dilakukan secara berkelompok dengan menjunjung kerjasama yang tinggi untuk dapat menyelesaikan suatu pekerjaan yang telah ditentukan sebelumnya berupa tujuan dari suatu organisasi.

Administrasi Negara secara umum dapat diartikan sebagai suatu proses kerjasama yang dilakukan oleh semua Aparatur Negara untuk dapat menjalankan tugasnya sesuai dengan kebijakan Negara yang telah ditentukan sebelumnya. Prajudi Atmosudirdjo, dalam bukunya Hukum Administrasi Negara memberikan definisi administrasi negara, bahwa Administrasi Negara mempunyai 3 (tiga) arti yaitu: a) ebagai aparatur negara, aparatur pemerintah atau sebagai institusi politik (kenegaraan); b) administrasi negara sebagai fungsi atau sebagai aktivitas melayani pemerintah, yakni sebagai kegiatan pemerintah operasional; dan c) administrasi negara sebagai proses teknis penyelenggaraan undang-undang (Mustafa, $2001: 6$ ).

Menurut Edward H. Litchfield dalam Notes on A General Theory of Administration, yang dikutip dan diterjemahkan oleh Inu Kencana dalambukunya Sistem Administrasi Negara Republik Indonesia menyatakan bahwa: "Administrasi negara adalah suatu studi mengenai bagaimana bermacam-macam badan pemerintah diorganisasi, diperlengkapi dengan tenaga-tenaganya, dibiayai, digerakkan, dan dipimpin." (Kencana, 2003:33).

Adapun menurut Dimock dalam bukunya Public Administration, mengemukakan bahwa: "Public Administration is the activity of the State in the exercise of its political power." (Administrasi negara adalah kegiatan negara dalam melaksanakan kekuasaan atau kewenangan politiknya. (Handayaningrat, 1996:3).

D.A. Sumantri (1988: 3-4) menjelaskan bahwa alat perlengkapan mulai memperhatikan pemenuhan kebutuhan umum itu dengan jalan: a. Mengikrarkan peraturan-peraturan yang bersifat keharusan dan bersifat larangan. b. Dengan mengadakan kontrol atau pengawasan. c. Dengan menentukan syarat-syarat yang harus dipenuhi oleh pihak yang mengusahakan kepentingan umum. d. Penguasa sendirilah menyediakan jasa dan alat-alat untuk memenuhi kebutuhan umum itu atau 
campurtangan penguasa berwujud menyediakan bantuan uang atau subsidi dari Keuangan Negara.

Selanjutnya dijelaskan Soemantri untuk mengurusi kebutuhan itu diperlukan orang-orang tertentu maka alat-alat perlengkapan negara mengangkat orang tersebut dan diberi kewenangan tertentu, dengan timbulnya kebutuhan kolektif maka nampak adanya kebutuhan: a. Orang-orang atau lembaga tertentu yang diserahi kewajiban itu harus mengadakan pengkhususan dan kepada mereka perlu diberi wewenangwewenang tertentu. b. Untuk menjamin terpenuhinya kewajiban-kewajibannya dengan sewajarnya. Dengan demikian timbul: 1) Peraturan-peraturan tentang cara pembentukan organ-organ khusus, pengangkatan atau penunjukan dengan cara lain, dari pada orang-orang yang diserahi tugas dalam organ-organ itu. Selanjutnya diadakan syarat-syarat tertentu. 2) Peraturan-peraturan yang bertujuan menjamin pelaksanaan tugas dengan benar-benar dan tidak memihak. 3) Peraturan tentang kewajiban di satu pihak dan di lain pihak tentang hak-hak untuk menjamin dan mengambil manfaat oleh anggota masyarakat, untuk menjamin terdapat keseimbangan. 4) Peraturan-peraturan pembayaran sebagai kontra prestasi. 5) Peraturan yang mencegah timbulnya kerusuhan, kerugian atau bahaya yang disebabkan oleh kerjaannya alat perlengkapan tersebut.

Proses-proses yang menjadi uraian diatas lebih mendekatkan kita pada konsep administrasi negara, C.S.T. Kansil (1984: 11) menjelaskan ada 3 (tiga) arti dari pada administrasi negara yaitu: a. Sebagai aparatur negara, aparatur pemerintah, atau sebagai institusi politik (kenegaraan); artinya meliputi organ yang berada di bawah pemerintah, mulai dari presiden, menteri (termasuk sekretaris jenderal, direktur jenderal, inspektur jenderal), gubernur, bupati, dan sebagainya, singkatnya semua organ yang menjalankan administrasi negara. b.Sebagai fungsi atau aktivitas, yakni sebagai kegiatan "pemerintahan" artinya sebagai kegiatan "mengurus kepentingan negara" c. Sebagai proses teknis penyelenggaraan undang-undang, artinya meliputi segala tindakan aparatur negara dalam menyelenggarakan undang-undang.

Rozali Abdullah (1986: 1) mengutip pendapat Utrecht buku Pengantar Hukum Administrasi Negara Indonesia sebagai berikut: Prof. Oppenheim mengartikan hukum tata negara sebagai hukum yang memberikan gambaran tentang negara dalam keadaan yang tidak bergerak staat in rust sedangkan hukum administrasi negara mempertunjukan kepada kita negara dalam keadaan bergerak staat in beweging. Selanjutnya dalam kutipan Bayu yang berbeda menurut Utrecht, mengatakan hukum administrasi negara menguji hubungan hukum istimewa yang diadakan untuk memungkinkan para penjabat ambtsdragers (administrasi negara) melakukan tugas mereka yang khusus.

Utrecht (1986: 74) sebagaimana mengutip van Vollenhoven berpendapat bahwa: Hukum administrasi negara itu meliputi seluruh lapangan aksi activiteitsceld bahanbahan pemerintah. Maka dari itu hukum administrasi negara itu tidak hanya terdapat dalam lapangan pekerjaan bestuur (pemerintah dalam arti kata sempit) saja, melainkan juga lapangan pekerjaan fungsi polisi, fungsi mengadili dan fungsi membuat peraturan. Dalam sistem van Vollenhoven hukum acara pidana dan hukum acara sipil termasuk juga hukum administrasi negara.

C.S.T. Kansil (1984: 17-18) sebagaimana mengutip pendapat Prajudi Atmosudirjo menyatakan bahwa ada dua pengertian administrasi yaitu, administrasi dalam arti sempit dan administrasi dalam arti yang luas: Dalam pengertian sempit, 
administrasi berarti tata usaha office work. Dinegeri Belanda pengertian Bestuur dimaksud dalam pengertian administrasi, sedang bagi Indonesia pengertian Bestuur mengandung arti khusus dalam gerak aktivitas dalam negeri yang kini dikenal dengan "pamong praja", seperti dahulu Departement van Binnenlands Bestuur.

Administrasi dalam pengertian luas, dapat ditinjau dari tiga sudut yakni: a. Administrasi sebagai proses dalam masyarakat. b. Administrasi sebagai suatu jenis kegiatan manusia. c. Administrasi sebagai kelompok orang yang secara bersama-sama sedang menggerakkan kegiatan-kegiatan diatas. Dengan perkataan lain administrasi dapat ditinjau dari: a. Sudut proses (administrasi sebagai proses) b. Sudut fungsi (administrasi dalam arti fungsional) c. Sudut kepranataan (institusional), administrasi dalam kepranataan.

Selanjutnya dijelaskan C.S.T. Kansil (1984) tentang rumusan administrasi sebagai berikut: Ditinjau dari sudut proses, maka administrasi merupakan keseluruhan proses-proses, yang dimulai dengan proses pemikiran, proses pengaturan, proses pencapaian tujuan sampai dengan proses tercapainya tujuan itu. Untuk mencapai suatu tujuan, orang yang harus memikirkan dulu kemudian mengatur, dan menentukan bagaimana caranya mencapai tujuan itu, lalu pencapaiannya sendiri sampai ke tujuan. Keseluruhan dari aktivitas-aktivitas tersebut dirangkum menjadi suatu pengertian administrasi. Ditinjau dari sudut fungsi/tugas, administrasi berarti keseluruhan tindakan dari aktivitas- aktivitas yang mau tidak mau harus dilakukan dengan sadar oleh perusahaan (negara) atau kelompok orang-orang yang berkedudukan sebagai administrator atau pemimpin suatu usaha.

Utrecht (1986: 77) sebagaimana mengutip pendapat Logemann menyatakan bahwa: hukum administrasi negara mempelajari sifat, bentuk dan akibat perbuatan hukum istimewa sekaliannya yang dilakukan para pejabat dalam menjalankan tugas mereka.

Victor Situmorang (1989: 10-11) menjelaskan segi pengertian administrasi negara dapat dibagi menjadi 4 (empat) macam pengertian administrasi negara yang mana satu sama lain tidak dapat dipisahkan, yakni dari sebagai berikut: a. Fungsional: administrasi negara adalah keseluruhan fungsi-fungsi yang dijalankan pemerintah beserta aparatur yang dipimpinnya. b. Institusional: administrasi negara adalah keseluruhan daripada jabatan-jabatan dan satuan-satuan organisasi negara yang merupakan suatu aparatur negara yang secara langsung dipimpin dan digerakkan oleh pemerintah. c. Proses: administrasi negara adalah keseluruhan daripada aktivitasaktivitas negara yang berasal dari atau sumber pada kehendak- kehendak, penetapanpenetapan atau perintah-perintah dari pemerintah. d.Hukum: administrasi negara adalah pelaksana dan atau penyelenggaraan daripada Undang-undang dalam arti luas.

Selanjutnya dijelaskan Victor Situmorang jika administrasi ditinjau dari sudut hukum maka fungsi administrasi sebagai fungsi hukum terdiri dari: a. Pengaturan administrasi, yakni penetapan peraturan-peraturan administratif, berupa Peraturan Pemerintah, Peraturan Presiden Peraturan Menteri dan sebagainya yang bersifat administratif, artinya berupa interpretasi penjabaran, petunjuk atau instruksi pelaksanaan undang-undang. b. Tata Pemerintahan, yakni penggunaan kekuasaan yuridis formal negara terhadap orang-orang penduduk negara dan segala apa yang terdapat dalam wilayah negara di dalam rangka menegakkan pemerintahan negara secara nyata, penggunaan kekuasaan ini adalah untuk menjalankan dan mencapai secara yuridis, segala apa yang menjadi fungsi, tugas, kewajiban atau tujuan dari negara dalam mengurusi kehidupan rakyat. c. Kepolisian administratif, yakni penegakkan hukum secara langsung berupa pengawasan dan pemeliharaan ketertiban 
serta keamanan terhadap pelaksanaan hukum yang bersifat pembinaan dan pendidikan masyarakat. d. Penyelesaian perselisihan secara administratif, yakni penyelesaian perkara-perkara atau persengketaan yang tidak dapat diselesaikan oleh Pengadilan Justisi, yaitu perkara-perkara administratif.

Hukum menjadi dasar utama dalam melangsungkan kehidupan untuk menjamin asas tertib dan disiplin agar berlangsung keteraturan, terjaminnya rasa kemerdekaan, rasa aman-nyaman, dan tertib. Hukum menjadi payung diantara segala jenis tindak dan perilaku manusia untuk mencapai asas perlindungan manusia. Sejalan dengan pemikiran tersebut mengenai sanksi, Philipus M. Hadjon, dkk (2002: 247) menyatakan bahwa: Peran penting pada pemberian sanksi di dalam hukum administrasi memenuhi hukum pidana. Perbedaan antara sanksi administrasi dan sanksi pidana dapat dilihat dari tujuan pengenaan sanksi itu sendiri. Sanksi administrasi ditujukan kepada perbuatan pelanggarannya, sedangkan sanksi pidana ditujukan kepada sipelanggar dengan memberi hukuman berupa nestapa. Sanksi administrasi dimaksud agar perbuatan pelanggaran itu dihentikan. Sifat sanksi adalah "reparatoir" artinya memulihkan pada keadaan semula. Di samping itu perbedaan antara sanksi pidana dan sanksi administrasi ialah tindakan penegakan hukumnya. Sanksi administrasi diterapkan oleh pejabat tata usaha negara tanpa harus melalui prosedur peradilan, sedangkan sanksi pidana hanya dapat dijatuhkan oleh hakim pidana melalui proses peradilan.

Mendukung pernyataan Philipus M. Hadjon, dkk (2002: 27-28) diatas masih dalam ulasan yang sama tentang administrasi demikian dikutip dalam Van WijkKonijnenbelt dalam bukunya Hoodfdstukken van Administratief recht, 1948, p.1 sebagai berikut: Hukum Administrasi, hukum tata pemerintahan semuanya menyangkut administrasi, bestuur, besturen. Secara umum dapat dikatakan: Hukum administrasi merupakan instrument yuridis bagi penguasa untuk secara aktif terlibat dengan masyarakat dan pada sisi lain hukum administrasi merupakan hukum yang memungkinkan anggota masyarakat mempengaruhi penguasa dan memberikan perlindungan terhadap penguasa.

\section{Penutup}

Hukum menjadi dasar utama dalam melangsungkan kehidupan untuk menjamin asas tertib dan disiplin agar berlangsung keteraturan, terjaminnya rasa kemerdekaan, rasa aman-nyaman, dan tertib. Hukum menjadi payung diantara segala jenis tindak dan perilaku manusia untuk mencapai asas perlindungan manusia. Sanksi-sanksi merupakan bagian penutup yang penting di dalam hukum, juga dalam hukum administrasi. Pada umumnya tidak ada gunanya memasukkan kewajiban-kewajiban atau larangan- larangan bagi para warga didalam peraturan perundang-undangan tata usaha negara, manakala aturan-aturan tingkah laku tidak dapat dipaksakan oleh tata usaha negara (dalam hal dimaksud diperlukan). Selanjutnya pelaksanaan suatu sanksi pemerintahan berlaku sebagai suatu keputusan (ketetapan) yang memberikan beban belastende beschkking. Hal itu membawa serta hakikat (sifat) dari sanksi. 


\section{Daftar Pustaka}

Ernst. Utrecht, Pengantar Hukum Administrasi Negara Indonesia, Bandung, 1960.

Debora Angelia Pardosi, Peran Jabatan Fungsional Auditor Terhadap Peningkatan Kinerja Birokrat Di Lingkungan Inspektorat Provinsi Jawa Tengah, Soumatera Law Review, Volume 1, Nomor 2, 2018.

H. A. Muin Fahmal,. Peran Asas-asas Umum Pemerintahan Yang Layak Dalam Mewujudkan Pemerintahan yang Bersih, Yogyakarta, 2006.

Indroharto, Usaha Memahami Undang-Undang Tentang Peradailan Tata Usaha Negara, Buku I, Beberapa Pengertian Dasar Hukum Tata Usaha Negara, Jakarta. 1993.

Lili Rasjidi dan B, Arief Sidarta, filsafat Hukum Mazhab dan Refleksinya, Bandung. 1989.

Muhammad Afif, Penemuan Hukum Oleh Hakim Terhadap Kasus Carok Akibat Sengketa Tanah Dalam Masyaraka Madura, Soumatera Law Review, Volume 1, Nomor 2, 2018.

M. Solly Lubis, Hukum Tata Negara, Bandung, 2002.

Miriam Budiarjo,Dasar-dasar Ilmu Politik, Jakarta.1988.

Philipus M Hadjon, ,dkk, Pengantar Hukum Adminstrasi Negara, 1997.

Ridwan H. R., Hukum Administrasi Negara, Yogyakarta, 2002.

S.F. Marbun, dkk., Dimensi-Dimensi Pemikiran Hukum Administrasi Negara, Yogyakarta, 2001.

Suwoto Mulyosudarmo, Peralihan Kekuasaan; Kajian Teoritis dan Yuridis Terhadap Pidato Newaksara, Jakarta, 1997.

Sjachran Basah, Eksistensi dan Tolok Ukur Badan Peradilan Administrasi di Indonesia, Bandung, 1985.

Sudargo Gautama, Pengertian Tentang Negara Hukum, Bandung, 1983. 